\title{
PHÂN TÍCH CHI PHÍ TRỰC TIẾP Y TẾ TRONG ĐIỀU TRI NỘI TRÚ BÊ̂NH VIÊM PHỔI DO VI KHUẨN CHO TRẺ EM CÓ BẢO HIỂM Y TẾ TẠI BÊ̂NH VIỆN NHI LÂM ĐỒNG GIAI ĐOẠN 2019-2020
}

\author{
Nguyễn Trọng Duy Thức ${ }^{1}$, Lê Thọ ${ }^{1}$, Đồng Sỹ Quang1, \\ Trần Thị Ngọc Vân ${ }^{2}$, Hoàng Thy Nhạc Vũ̃
}

\section{TÓM TẮT}

Đăt vấn đề: Nghiên cứu được thực hiện nhằm phân tích chi phí trực tiếp y tế trong điều trị nội trú bệnh viêm phổi do vi khuẩn trên đối tượng trẻ em có BHYT tại Bệnh viện Nhi Lâm Đồng giai đoạn 20192020. Đối tượng và phương pháp nghiên cứu: Nghiên cứu mồ tả cắt ngang, thông qua hồi cứu hồ sơ bểnh án điều tri nội trú viêm phổi do vi khuẩn của toàn bộ 2243 bệnh nhi có BHYTtại Bệnh viện trong giai đoạn từ $1 / 1 / 2019$ đến $31 / 12 / 2020$. Kết quả: Trong các loại chi phí trực tiếp y tế trong điều trị viêm phổi do vi khuẩn trên đối tượng trẻ em, chi phí ngày giường chiếm tỷ lệ cao nhất $(64,1 \%)$; tiếp đến là chi phí thuốc (14,9\%). Trong tổng chi phí dành cho thuốc, kháng sinh chiếm tỷ lệ cao nhất $(69,6 \%)$. Nghiên cứu ghi nhận có sự khác biệt trong chi phí y tế trực tiếp theo nhóm tuổi, mức độ nặng của bệnh, biến chứng suy hô hấp $(p<0,05)$. Kểt luận: Những thông tin về chi phí trong điêu trị viêm phổi do vi khuẩn, một nhóm bệnh có tý trọng cao tại Bệnh viện Nhi Lâm Đồng, giúp Bệnh viện có những chính sách điêu chỉnh ngân sách và viện phí phù hợp, góp phần nâng cao chất lượng dịch vụ khám chữa bệnh tại Bệnh viện.

Tư khóa: Viêm phổi do vi khuẩn, chi phí trực tiếp y tế, chi phí thuốc, bệnh nhi, Bệnh viện Nhi Lâm Đồng

\section{SUMMARY}

ANALYSIS OF DIRECT MEDICAL COST FOR PEDIATRICS WITH BACTERIAL

PNEUMONIA AT LAM DONG CHILDREN'S

HOSPITAL IN THE PERIOD OF 2019-2020

Objectives: This study was conducted to analyze the direct medical cost in treatment of inpatient pediatrics with bacterial pneumonia who had health insurance at Lam Dong Children's Hospital in the period of 2019-2020. Subjects and methods: A cross-sectional descriptive study was carried out through reviewing retrospective treatment records of all 2243 inpatient pediatricswith bacterial pneumonia who had health insurance at the hospital from $1 / 1 / 2019$ to $31 / 12 / 2020$. Results: Among direct medical cost components, the bed dayscost accounted for the highest proportion $(64.1 \%)$, followed by drug costs (14.9\%). Among the drug cost components,

\footnotetext{
${ }^{1}$ Bệnh viện Nhi Lâm Đồng,

${ }^{2}$ Đại Học Y Dược TP. Hồ Chí Minh

Chịu trách nhiệm chính: Hoàng Thy Nhạc Vũ

Email: hoangthynhacvu@ump.edu.vn

Ngày nhận bài: 15/5/2021

Ngày phản biện khoa học: 11/6/2021

Ngày duyệt bài: 12/7/2021
}

antibiotics accounted for the highest proportion $(69.6 \%)$. The study noted the difference in the total direct medical cost among age groups, disease severities, and respiratory failure complications $(p<0.05)$. Conclusion: The information about the direct medical cost of bacterial pneumonia, a condition with the highest prevalent proportion at Lam Dong Children's Hospital, can help the Hospital to optimize policies and adjust budget, in order to contribute to the improvementof the quality of medical examination and treatment services at the Hospital.

Keywords: Bacterial pneumonia, direct medical costs, drug costs, pediatrics, Lam Dong children's hospital.

\section{I. ĐẶT VẤN ĐỀ}

Theo thống kê của tổ chức y tễ thế giới (WHO), viêm phổi là tình trạng bệnh lý gây tử vong hàng đâuu ở trẻ em dưới 5 tuổi trên toàn thếgiới[1]. Trẻ em mắc viêm phổi do nhiều nguyên nhân, trong đó nhiễm vi khuẩn là một trong những nguyên nhân chính ${ }^{[2]}$. Tại Việt Nam hiện nay chưa có nhiều nghiên cứu đánh giá tầm quan trọng của BHYT trong việc hỗ trợ chi phí khám chữa bệnh cho trẻ em mắc viêm phổi do vi khuẩn. Bệnh viêm phổi do vi khuẩn là bệnh phổ biến tại Bệnh viện Nhi Lâm Đồng, với chi phí khám và chữa bênh chiếm đến $42 \%$ tổng chi phí trực tiếp y tế tại Bệnh viện ${ }^{[3]}$. Những thông tin liên quan đến chi phí điều trị bệnh có vai trò quan trọng trong hoạt động quản lý, tạo căn cứ giúp Bệnh viện có những chính sách phân bổ ngân sách một cách hợp lý, góp phần tối ưuhoạt động và chất lượng dịch vụ của Bệnh viện Nhi Lẩm Đồng. Nghiên cứu được thực hiện nhằm phân tích chi phí trực tiếp y tếtrong điểu trị nội trú bệnh viêm phổi do vi khuẩn trên đối tượng bệnh nhi có BHYT tại Bệnh viện Nhi Lâm Đồng giai đoạn 2019-2020.

\section{II. ĐỐI TƯƠNGG VÀ PHƯƠNG PHÁP NGHIÊN CỨU}

2.1 Thiết kế nghiên cứu: Nghiên cứu mô tả cắt ngang, được thực hiện thông qua hồi cứu hồ sơ bệnh án của bểnh nhi điều trị nội trú bệnh viêm phổi do vi khuẩn tại Bệnh viện Nhi Lâm Đồng.

2.2 Mẫu nghiên cứu: Mẫu nghiên cứu bao gồm toàn bộ2.243 bệnh nhiđược chẩn đoánmắc viêm phổi do vi khuẩn, hoàn thành hết một lượt điêu trị trong giai đoạn từ 1/1/2019 đển 
31/12/2020 tại Bệnh viện Nhi Lâm Đồng, và có tham gia BHYT. Những trường hợp không được đưa vào mẫu nghiên cứu là những bệnh nhi không bắt đầu điều trị tại Bệnh viện Nhi Lâm Đồng,nhận điều trị nhưng bị ngắt quãng, hồ sơ bệnh ánkhông đủ thông tin, mắc bệnh kèm theo, hoặc tử vong trong quá trình điều trị.

2.3 Tổng hợp và thu thập dữ liệu: Từ hồ sơ bệnh án, nghiên cứu đã thu thập các thông tin vể đặc điểm giới tính, tuổi, mức độ nặng của bệnh, biến chứng suy hô hấp, và các loại chi phí bao gồm khám bệnh, xét nghiệm, chẩn đoán hình ảnh-thăm dò chức năng, thuốc, phẫu thuâatthủ thuật, vật tư y tế, và ngày giường. Mẫu nghiên cứu được chia thành hai nhóm mức độ nặng của bênhh, dựa theo phác đồ điều trị viêm phổi của Tổ chức Y tế thế giới và phác đồ điều trị tại Bệnh viện Nhi Lâm Đồng.

2.4 Xử lý thống kê: Đặc điểm của bệnh nhiđược mô tả bằng tân suất và tỷ lệ phần trắm, các thành phần chi phí trực tiếp y tế được mô tả thông qua tỷ lệ phần trăm, giá trị nhỏ nhất, giá trị lớn nhất, và giá trị trung vị. Cơ cấu chi phí theo nhóm thuốc điều trị, nhóm thuốc kháng sinh, phẫu thuật-thủ thuật, xét nghiệm, chẩn đoán hình ảnh-thăm dò chức năngđược mô tả thông qua tỷ lệ phần trăm. Giá trị chi phí trực tiếp y tế được so sánh theo giới tính, nhóm tuổi, biến chứng suy hô hấp, và mức độ nặng của bệnh thông qua kiểm định Mann-Whitney hoặc Kruskal-Wallis, với $p<0,05$ ứng với sự khác biệt có ý nghĩa thống kê. Dữ liệu được xử lý bằng phần mềm thống kê SPSS 25.

\section{KẾT QUẢ NGHIÊN CỨU}

3.1 Đặc điểm của mẫu nghiên cứu. Trong 2.243 bệnh nhi có BHYT, điều trị nội trú bệnh viêm phổi do vi khuẩntại Bệnh viện Nhi Lâm Đồng giai đoạn 2019-2020; nam chiếm 56,0\%; nhóm tuổi từ 1 đến 3 tuổi chiếm 53,5\%; số lượng bệnh nhi có biến chứng suy hô hấp chiếm tỷ lệ $7,6 \%$; và viêm phổi nặng chiếm $88,8 \%$. (Hình 1 ).

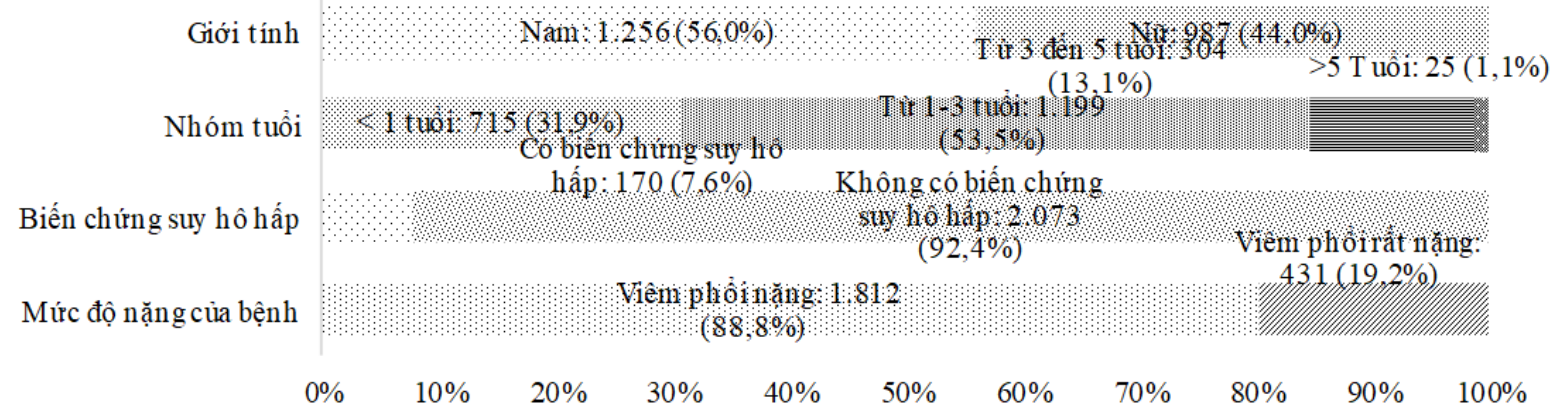

Hinh 1. Mô tả đặc điểm của 2.243 bệnh nhi có BHYT, điều trị nội trú bệnh viêm phổi do vi khuẩn cho trẻ em có BHYT tại Bệnh viện Nhi Lâm Đồng giai đoạn 2019-2020.

\subsection{Cơ cấu chi phí trực tiếp y tế}

Bảng 1. Mô tả chi phí trực tiếp y tế trong điều trị nội trú bệnh viêm phổi do vi khuẩn cho bệnh nhi có BHYT tại Bệnh viện Nhi Lâm Đồng giai đoạn 2019-2020 theo mức độ nặng của bệnh(đơn vị: đồng)

\begin{tabular}{|c|c|c|c|}
\hline \multirow{2}{*}{$\begin{array}{l}\text { Loại } \\
\text { chi phí }\end{array}$} & \multicolumn{3}{|c|}{ Tống chi phí Trung vị (min-max) } \\
\hline & $\begin{array}{l}\text { Viêm phối nă̆ng } \\
(\mathrm{N}=1.812)\end{array}$ & $\begin{array}{l}\text { Viêm phối rất nặng } \\
(\mathrm{N}=431)\end{array}$ & $\begin{array}{l}\text { Mâu nghiên cứu } \\
(\mathrm{N}=2.243)\end{array}$ \\
\hline $\begin{array}{c}\text { Trực tiếp } \\
\text { y tế }\end{array}$ & $\begin{array}{c}3.332 .973 .332 \\
1.775 .585(952.711- \\
2.948 .201)\end{array}$ & $\begin{array}{c}1.367 .146 .147 \\
3.033 .352(2.255 .693- \\
4.657 .360)\end{array}$ & $\begin{array}{c}4.700 .119 .479 \\
1.907 .600(952.711- \\
4.657 .360)\end{array}$ \\
\hline $\begin{array}{l}\text { Ngày } \\
\text { giường }\end{array}$ & $\begin{array}{c}2.160 .723 .250 \\
1.122 .600(712.000- \\
2.308 .000)\end{array}$ & $\begin{array}{c}846.251 .850 \\
1.871 .000(1.122 .600- \\
3.466 .550)\end{array}$ & $\begin{array}{c}3.006 .975 .100 \\
1.246 .000(712.000- \\
3.466 .550)\end{array}$ \\
\hline Thuốc & $\begin{array}{c}502.011 .540 \\
243.308(46.046-915.305)\end{array}$ & $\begin{array}{c}198.215 .469 \\
418.861(81.083-1.946 .813)\end{array}$ & $\begin{array}{c}700.227 .009 \\
264.682(46.046-1.946 .813)\end{array}$ \\
\hline $\begin{array}{l}\text { Thủ thuật } \\
\text { Phẫu thuật }\end{array}$ & $\begin{array}{l}248.914 .500 \\
0(0-588.000)\end{array}$ & $\begin{array}{c}159.797 .300 \\
294.000(10.800-938.400)\end{array}$ & $\begin{array}{c}408.711 .800 \\
142.800(0-938.400)\end{array}$ \\
\hline $\begin{array}{l}\text { Vật tư } \\
\text { y tế }\end{array}$ & $\begin{array}{c}173.586 .142 \\
90.380(27.830-384.982)\end{array}$ & $\begin{array}{c}68.271 .828 \\
142.690(81.700-495.724)\end{array}$ & $\begin{array}{c}241.857 .970 \\
96.970(27.830-495.724)\end{array}$ \\
\hline
\end{tabular}




\begin{tabular}{|c|c|c|c|}
\hline $\begin{array}{c}\text { Chấn đoán hìnł } \\
\text { ảnh, Thăm dò } \\
\text { chức năng }\end{array}$ & $\begin{array}{c}101.918 .500 \\
65.400(0-419.100)\end{array}$ & $\begin{array}{c}40.987 .100 \\
65.400(64.200-375.200)\end{array}$ & $\begin{array}{c}142.905 .600 \\
65.400(0-419.100)\end{array}$ \\
\hline Xét nghiệm & $\begin{array}{c}83.305 .400 \\
40.400(0-418.200)\end{array}$ & $\begin{array}{c}38.753 .100 \\
52.300(40.000-841.900)\end{array}$ & $\begin{array}{c}122.058 .500 \\
40.400(0-841.900)\end{array}$ \\
\hline Khám bệnh & $\begin{array}{c}62.514 .000 \\
34.500(34.500-34.500)\end{array}$ & $\begin{array}{c}14.869 .500 \\
34500(34500-34500)\end{array}$ & $\begin{array}{c}77.383 .500 \\
34.500(34.500-34.500)\end{array}$ \\
\hline
\end{tabular}

Chi phí trực tiếp y tế cao nhất cho một trường hợp viêm phối nặng là 2.948.201 đồngvà môt trường hợp viêm phổi rất nặng là 4.657.360 đồng. Số trường hợp mắc viêm phổi rất nặng chiếm 19,2\% tổng số bệnh nhi và có chi phí trực tiếp y tế chiếm 29\% tổng chi phí. (Bảng 1).

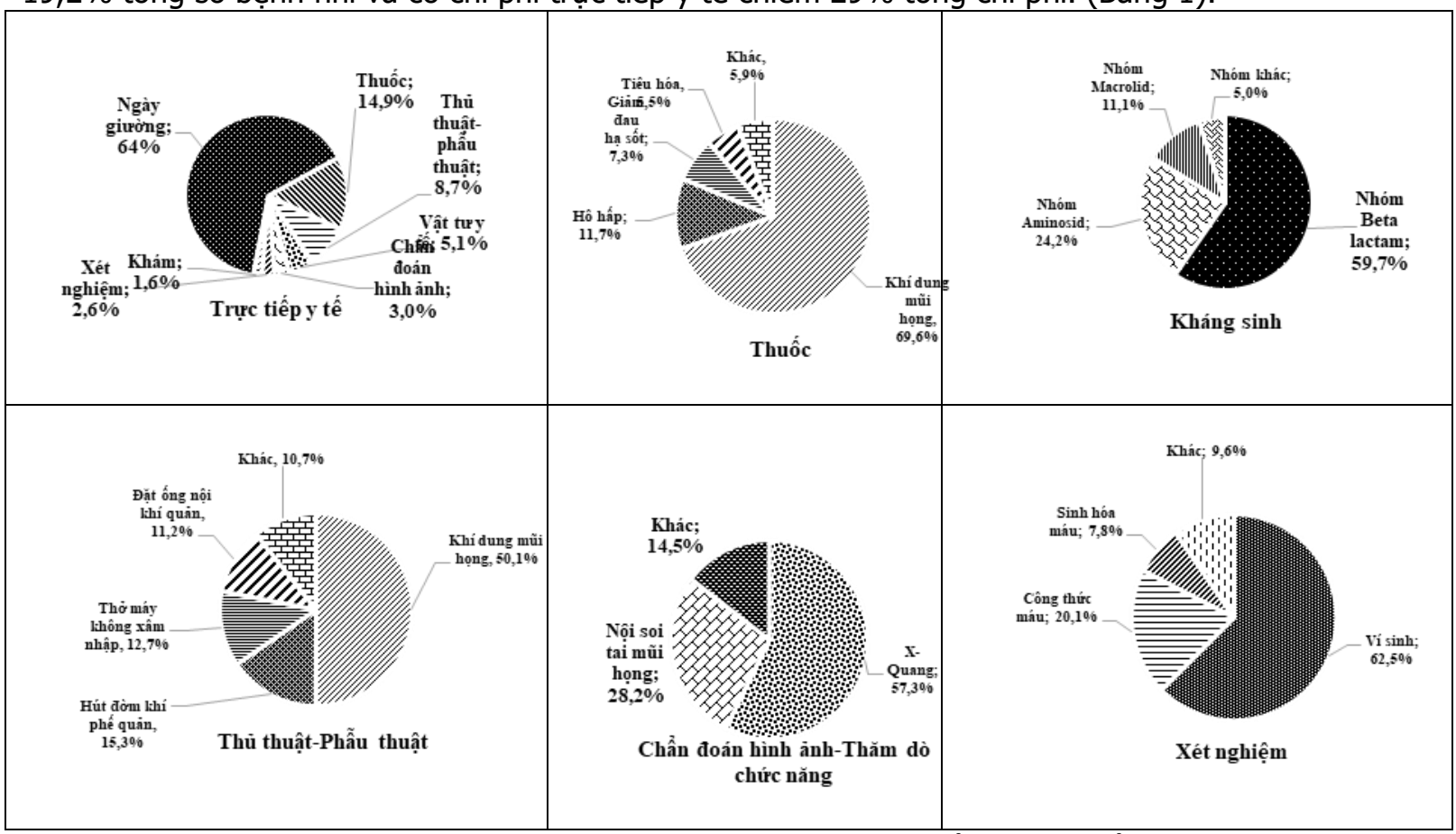

Hình 2. Chi phí trực tiếp y tế trong điều trị nội trú bệnh viêm phổi do vi khuẩn cho trẻ em có BHYT tại Bệnh viện Nhi Lâm Đồng giai đoạn 2019-2020 (đồng)

Bảng 2. So sánh chi phí trực tiếp y tế theo đặc điểm của mẫu nghiên cứu(đồng)

\begin{tabular}{|c|c|c|c|c|}
\hline \multicolumn{2}{|c|}{ Đặc điểm } & Tổng chi phí & Trung vị (Min-max) & \multirow{3}{*}{$\frac{\mathbf{p}}{0,073}$} \\
\hline \multirow{2}{*}{ Giới tính } & Nam & 2.653 .684 .922 & $1.941 .115(952.711-4.657 .360)$ & \\
\hline & Nữ & 2.046 .434 .557 & $1851230(1111306-4621184)$ & \\
\hline \multirow{4}{*}{ Nhóm tuổi } & $<1$ tuối & 1.476 .243 .208 & $1.831 .590(952.711-4.657 .360)$ & \multirow{4}{*}{$<0,001$} \\
\hline & Từ 1-3 tuối & 2.519 .996 .789 & $1.938 .899(1.147 .394-4.621 .184)$ & \\
\hline & Từ 3-5 tuối & 643.547 .525 & $1.973 .065(1.151 .942-4.396 .850)$ & \\
\hline & $>5$ tuối & 60.331 .957 & $2.113 .807(1.373 .269-4.333 .112)$ & \\
\hline \multirow{2}{*}{$\begin{array}{l}\text { Biến chứng } \\
\text { suy hô hấp }\end{array}$} & Có & 633.955 .520 & $1.775 .585(3.237 .156-4.657 .360)$ & \multirow[b]{2}{*}{$<0,001$} \\
\hline & Không & 4.066 .163 .959 & $3.033 .352(952.711-3.235 .960)$ & \\
\hline \multirow{2}{*}{$\begin{array}{l}\text { Mức độ nặng } \\
\text { của bệnh }\end{array}$} & Viêm phối nặng & 3.332 .973 .332 & $1.775 .585(952.711-2.948 .201)$ & \multirow{2}{*}{$<0,001$} \\
\hline & $\begin{array}{c}\text { Viêm phối rất } \\
\text { nặng }\end{array}$ & 1.367.146.147 & $3.033 .352(2.255 .693-4.657 .360)$ & \\
\hline
\end{tabular}

Thành phần chi phí y tế trực tiếp trong điều trị nội trú viêm phổi do vi khuẩn trong mẫu nghiên cứu, kết quả ghi nhận chi phí ngày giường và thuốc chiếm tỷ lệ cao nhất lần lượt là (64\%; 14,9\%); thấp nhất là chi phí khám bệnh $(1,7 \%)$. Trong chi phí thuốc, kháng sinh chiếm tỷ lệ cao nhất $(69,6 \%)$, trong đó nhóm kháng sinh Beta-lactam chiếm tỷ lệ (72,3\%).

Đối với chi phí xét nghiệm, Xét nghiệm vi sinh và Công thức máu tỷ lệ cao nhất lần lượt là $(62,5 \% ; 20,1 \%)$. X-Quang và nội soi tai-mũihọng là hai loại chi phí chiếm tỳ lệ cao nhất 
trong chi phí chẩn đoán hình ảnh-thăm dò chức năng lần lượt là $57,3 \%$ và $28,2 \%$. (Hình 2 ).

Khi so sánh chi phí trực tiếp y tế giữa các nhóm tuổi, mức độ nặng của bệnh, biến chứng suy hô hấp cho thấy sự khác biệt có ý nghĩa thống kê với $p<0,05$. (Bảng 2).

Trong số tất cả thành phần chi phí y tế trực tiếp của mẫu nghiên cứu, kết quả ghi nhận chi phí ngày giường và chi phí thuốc chiếm tỷ lệ cao nhất (lần lượt là $64,1 \%$ và $14,9 \%$ ), chi phí khám bệnh chiếm tỷ lệ thấp nhất $(1,7 \%)$.

Xem xét từng loại chi phí, kết quả ghi nhận đối với chi phí thuốc, kháng sinh chiếm tỷ lệ cao nhất trong tổng chi phí thuốc $(69,6 \%)$, trong đó nhóm kháng sinh Beta-lactam chiếm tỷ lệ cao nhất trong tổng chi phí kháng sinh $(59,7 \%)$. Đối với chi phí xét nghiệm, xét nghiệm vi sinh và công thức máuchiếm tỷ lệ cao nhất (lần lượt là $62,5 \%$ và $20,1 \%$ ). Đối với chi phí chẩn đoán hình ảnh-thăm dò chức năng, $X$-Quang và nội soi tai-mũi-họng là hai loại chi phí chiếm tỷ lệ cao nhất (lần lượt là $57,3 \%$ và $28,2 \%$ ).

Kết quả so sánh chi phí trực tiếp y tế giữa các nhóm tuổi, mức độ nặng của bệnh, biến chứng suy hô hấp cho thấy có sự khác biệt có ý nghĩa thống kê với $p<0,05$. (Hình 2)

\section{BÀN LUÂ̂N}

Nghiên cứu đã cung cấp được các thông tin về đặc điểm điều trị nội trú bệnh viêm phổi do vi khuẩn của 2.243 bệnh nhi có BHYT tại Bệnh viện Nhi Lâm Đồng giai đoạn 2019-2020. Đa số bệnh nhi là nam, từ 1 tuổi trở lên, mắc viêm phổi nặng, và không có biến chứng suy hô hấp. Tại Bệnh viện, tổng chi phí trực tiếp y tế để điều trị nội trú viêm phổi do vi khuẩn cho 2.243 bệnh nhi trong giai đoạn 2019-2020 là hơn 4,7 tì đồng, trong đó chi phí ngày giường và chi phí thuốc chiếm tỷ lệ cao nhất. Kết quả này tương đồng với một nghiên cứu thực hiệntại Bệnh viện Bạch Mai ở trên cùng nhóm đối tượng ${ }^{[4]}$. Nghiên cứu ghi nhận đã có nhiều trường hợp bệnh nhi phảinằm điêu trị tại các phòng hồi sức cấp cứu và hồi sức tích cực, dẫn đến chi phí ngày giường chiếm tỷ lệ cao trong tổng cơ cấu chi phí điều trị trực tiếp y tế tại Bệnh viện Nhi Lâm Đồng.

Kháng sinh là loại thuốc chiếm tỷ lệ cao nhất trong cơ cấu chi phí thuốc tại Bệnh viện Nhi Lâm Đồng giai đoạn 2019-2020, tương đồng với kết quả thu được từ nghiên cứu tại bệnh viện Bạch $\mathrm{Mai}^{[4]}$. Kết quả này có thể được giải thích thổng qua vai trò chủ đạo của kháng sinh trong tất cả các phác đồ điều trị viêm phổi do vi khuẩn cho trẻ em hiện nay.Tại Bệnh viện Nhi Lâm Đồng, việc điều trị viêm phổi ở trẻ em được thực hiện theo hướng dẫn điêu trị củaWHO[1], cụ thể là sử dụng nhóm kháng sinh Beta-lactam ở cả hai mức độ nặng của viêm phổi, dẫn đến chi phí của nhóm kháng sinh Beta-lactam đã chiếm tỷ lệ cao nhất trong tổng cơ cấu chi phí thuốc kháng sinh.Kết quả nghiên cứu có ý nghĩa trong việc giúp Bệnh viện có những điều chỉnh phù hợp về quản lý sử dụng thuốc có tỷ lệ chi phí cao, đề ra những biện pháp tránh lạm dụng kháng sinh, giám sát sử dụng kháng sinh, được tiến hành bởi các dược sỹ hoặc các chuyên gia kiểm soát nhiễm khuẩn, từ đó giúp làm giảm chi phí thuốc và hiện tượng đề kháng kháng sinh ở trẻ em đã được ghi nhận tại Việt Nam[ ${ }^{[6]}$.

Với đặc thù là những chỉ định thường quy để chẩn đoán viêm phổi do vi khuẩn,chi phí chụp XQuang chiếm tỳ lệ cao nhất trong tổng cơ cấu chi phí chẩn đoán hình ảnh và thăm dò chức năng. Đặc điểm này cũng được ghi nhận trong một nghiên cứu tại Mỹ, trong đó chụp X-Quang được chỉ định ở $81,6 \%$ bệnh nhi viểm phổi và $80 \%$ trong số đó mắc viêm phổi do vi khuẩn ${ }^{[7]}$. Ngoài ra, xét nghiệm vi sinh, cụ thể là xét nghiệm nuôi cấy định danh vi khuẩn và xét nghiệm vi khuẩn kháng thuốc định tính, là những loại xét nghiệm thiết yếu để phục vụ trong điêuu trị chuyên sầu, dẫn đến kết quả là chi phí xét nghiệm vi sinh của mẫu nghiên cứu chiếm tỷ lệ cao nhất trong tổng cơ cấu chi phí dành cho xét nghiệm tại Bệnh viện Nhi Lâm Đồng.

Nghiên cứu ghi nhận chi phí điều trị trực tiếp y tế ở nhóm bệnh nhi có biến chứng suy hô hấp cao hơn ở nhóm bệnh nhi không có biến chứng suy hô hấp $(p<0,05)$, chi phí điều trị trực tiếp y tế ở nhóm bệnh nhi viêm phổi rất nặng cao hơn ở nhóm bệnh nhi viêm phổi nặng $(p<0,05)$. Một trong những nguyên nhân khiến chi phí tăng lên có thể là do phải sử dụng máy thở, cần sử dụng kỹ thuật đặt nội khí quản, và các khác biệt về chi phí thuốc, chi phí vật tư và chi phí ngày giường. Nghiên cứu cũng ghi nhận sự khác biệt về điều trị trực tiếp y tế giữa các nhóm tuổi $(p<0,05)$, có thể là do có sự khác biệt về liều lượng sử dụng thuốc cho từng độ tuổi làm thay đổi chi phí thuốc và chi phí ngày giường có đơn giá khác nhau tùy thuộc vào tình trạng bệnh và độ tuổi. Kết quả nghiền cứu có ý nghĩa trong việc giúp Iãnh đạo bệnh viện đề ra các giải pháp nhằm giảm chi phí y tế trực tiếp y tế cho người bệnh và phân bố nguồn lực y tế hợp lý.

\section{KẾT LUÂN}

Nghiên cứu đã phân tích chi phí trực tiếp y tế 
trong điêu trị nội trú bệnh viêm phổi do vi khuẩn cho trẻ em có BHYT tại Bệnh viện Nhi Lâm Đồng giai đoạn 2019-2020. Đây là những thông tin cân thiết để hoạch định chính sách, giúp bệnh viện có sự chuẩn bị về nguồn lực để nâng cao chất lượng dịch vụ khám chữa bệnh và tập trung nguồn lực vào các vấn đề ưu tiên. Các nghiên cứu tiếp theo có thể mở rộng phạm vi tính toán chi phí trong điều trị ngoại trú.

\section{TÀI LIẸU THAM KHẢO}

1. WHO (2018), Revised WHO classification and treatment of childhood pneumonia at health facilities, pp. 2-4.

2. Jain S, Seema Jain, Derek J. Williams (2015). Community-acquired pneumonia requiring hospitalization among U.S. children. N. Engl. J. Med. 372, pp. 835-845.

3. Bệnh viện Nhi Lâm Đồng (2020), Báo cáo tổng kết hoạt động bệnh viện giai đoạn 2019-2020.

4. Bui Thi Xuan, Pham Van Dem, Hoang Van Hung (2019). Analysis of cots for children treatment pneumonia in Bach Mai Ha Noi hospital from $10 / 2018$ to $3 / 2019$. VNU Journal of Science: Medical and Pharmaceutical Sciences, vol 35, n.2, pp. 96-104.

5. Alexander KC Leung, Alex HC Wong, Kam L Hon (2018). Community-Acquired Pneumonia in Children. Recent Patents on Inflammation \& Allergy Drug Discovery, Volume 12, Number 2, pp. 136-144.

6. Nguyen TK Phuong, Tran T Hoang, Pham H Van, Lolyta Tu, Stephen M Graham, Ben J Marais (2017). Encouraging rational antibiotic use in childhood pneumonia - focus on the Western Pacific region. PMC pneumonia, pp. 7-9.

7. Berce $V$, Tomazin $M$, Gorenjak $M$, Berce $T$, Lovrenčič B (2019). The Usefulness of Lung Ultrasound for the Aetiological Diagnosis of Community-Acquired Pneumonia in Children. Sci Rep, 9(1).

\section{NÔNG Độ 25 (OH)D HUYẾT THANH Ở TRẺ EM VIÊM PHỔI TẠI BỆNH VIỆN NHI TRUNG ƯO'NG}

\section{TÓM TẮT}

Vitamin $D$ có vai trò quan trong trong khả năng đề kháng của cơ thể. Mục tiêu: Khảo sát nồng độ 25 $(\mathrm{OH}) \mathrm{D}$ huyết thanh ở trẻ em viêm phổi và mối liên quan giữa nông độ $25(\mathrm{OH}) \mathrm{D}$ và mức độ nặng của viêm phổi. Phương pháp nghiên cứu: Nghiên cứu tiến cứu mô tả cắt ngang trên 84 bệnh nhân viêm phổi từ tháng 8 năm 2020 đến tháng 7 năm 2021 tại Khoa điều trị tự nguyện - Bệnh viện Nhi Trung Ương. Kết quả: Tuổi trung bình của bênh nhân $14,6 \pm 10,5$ tháng, viêm phổi nặng chiếm tỷ lệ 20,2\%. Nồng độ $25(\mathrm{OH}) \mathrm{D}$ trung bình là $91,8 \pm 41, \overline{7} \mathrm{nmol} / \mathrm{l}$ (dao động từ 29,1 nmol/l - là 261,6 nmol/l). Nồng độ $25(\mathrm{OH}) \mathrm{D}$ < 50 nmol/l chiếm tỷ lệ 11,9\%; từ 50 - 75 nmol/ I chiếm tỷ lệ $23,8 \%$; >75 nmol/l chiếm tỷ lệ $64,3 \%$. Nồng độ $25(\mathrm{OH}) \mathrm{D}$ thấp có nguy cơ mắc viêm phổi năng. Thời gian nằm viện kéo dài hơn ở trẻ có nồng độ 25(OH)D thấp. Kết luận: Trẻ viêm phổi có nồng đổ $25(\mathrm{OH}) \mathrm{D}$ thấp có nguy cơ bi viêm phổi nặng hơn nhóm có nồng độ 25(OH)D bình thường.

Tư khoá: viêm phôi, viêm phổi nặng, nồng độ 25(OH)D.

\section{SUMMARY \\ CONCENTRATION OF SERUM 25 (OH)D IN CHILDREN WITH PNEUMONIA AT THE}

\footnotetext{
${ }^{1}$ Trường Đại học Y Hà Nội

Chịu trách nhiệm chính: Nguyễn Thị Diệu Thúy

Email: nguyendieuthuyhmu@gmail.com

Ngày nhận bài: 10.5.2021

Ngày phản biện khoa học: 2.7.2021

Ngày duyệt bài: 12.7.2021
}

Sitthixay Phounsavath ${ }^{1}$, Nguyễn Thị Diệu Thúy ${ }^{1}$

\section{NATIONAL CHILDREN'S HOSPITAL}

Vitamin D plays an important role for health status. Objectives: To assess the concentration of serum $25(\mathrm{OH}) \mathrm{D}$ in children with pneumonia and the relationship between the serum 25(OH)D concentration and the severity of pneumonia. Methods: A cross-sectional descriptive prospective study in 84 children with pneumonia from August 2020 to July 2021 at the Vietnam National Children's Hospital. Results: The average age of children was $14.6 \pm 10.5$ months, with severe pneumonia accounting for $20.2 \%$. The concentration of $25(\mathrm{OH}) \mathrm{D}$ was $91.8 \pm 41.7 \mathrm{nmol} / \mathrm{l}$ (ranged from $29.1 \mathrm{nmol} / \mathrm{l}$ to $261.6 \mathrm{nmol} / \mathrm{l})$. The prevalance of children with $25(\mathrm{OH}) \mathrm{D}$ concentration < $50 \mathrm{nmol} / \mathrm{l}$ was $11.9 \%$. Low concentrations of $25(\mathrm{OH}) \mathrm{D}$ related to a risk of severe pneumonia. Longer hospital stay in children with low 25(OH)D concentrations. Conclusion: Children with low 25(OH)D concentrations have a high risk of severe pneumonia and a longer hospitalised stay.

Keywords: pneumonia, severe pneumonia, 25(OH)D concentrations.

\section{I. ĐĂT VẤN ĐỀ}

Theo Tổ chức $Y$ tế Thế giới (WHO), viêm phổi là nguyên nhân hàng đâu gây tử vong ở trẻ em. Có nhiều yếu tố làm tăng nguy cơ gây viêm phổi hoăc làm tăng mức độ nặng của viêm phổi, trong đó thiếu vitamin $\mathrm{D}$ là yếu tố được đề cập nhiều trong thời gian gần đây. Thiếu vitamin $D$ ngoài việc gây ra bệnh còi xương còn liên quan đến tình trạng nhiễm trùng đường hô hấp tái đi tái lại [1]. Các công trình nghiên cứu đã chứng 